\title{
ANALISA DESAIN PRODUK BOOKTORY TELLING SEBAGAI PERANGKAT PAMER BUKU AJAR UNGGULAN UNTUK DOSEN UNIPA SURABAYA
}

\author{
Yitno Utomo \\ Prodi Teknik Industri, Fakultas Teknologi Industri, Universitas PGRI Adi Buana Surabaya \\ email : yitnou@yahoo.com
}

\begin{abstract}
Booktory telling is a product that can be used as a book showing device. This study aims to find out attribute of books that tell about quality homes and provide designs based on respondents' satisfaction. The research sample amounted to 86 respondents who were conducted by purposive sampling technique. Data analysis uses Quality Function Deployment (QFD). The results of the analysis result in the importance of 3 Main Priorities namely; The Relatively Important Result (RI) of $25 \%$ is prioritized on the design of the red booktory telling product with HPL material. The Relatively Important Results (RI) of $21 \%$ are prioritized on strong selected ingredients. The materials selected by the 17\% Relative Important Results (RI) were prioritized on the part of the story that briefly told the book and the writer's wealth made from an artpaper screen.
\end{abstract}

Keywords: Booktory Telling, Quality Function Deployment (QFD)

\begin{abstract}
Booktory telling merupakan produk meuble yang peruntukkanya sebagai perangkat pamer buku. Penelitian ini bertujuan untuk mengetahui derajat kepentingan atribut produk booktory telling melalui house of quality dan memberikan gambaran desain berdasarkan keinginan responden. Sampel penelitian sejumlah 86 orang responden yang dilakukan dengan teknik purposive sampling. Analisa data menggunakan Quality Function Deployment (QFD). Hasil analisanya menghasilkan tingkat kepentingan terdapat 3 prioritas utama yaitu; Hasil Relative Important (RI) sebesar 25\% diprioritaskan pada desain produk booktory telling berwarna merah mencolok dengan dasaran terbuat dari bahan HPL. Hasil Relative Important (RI) sebesar $21 \%$ diprioritaskan pada pemilihan bahan yang kuat sehingga dipilih bahan multiplek Hasil Relative Important (RI) sebesar 17\% diprioritaskan pada bagian story telling yang menceritakan sekilas tentang buku dan identitas penulis yang terbuat dari artpaper screen.
\end{abstract}

Kata kunci : Booktory telling, Quality Function Deployment (QFD)

\section{PENDAHULUAN}

Universitas PGRI Adi Buana Surabaya, sedang giat-giatnya menerapkan buku ajar bagi para dosen di lingkungan perguruan tinggi yang berada di urutan 10 besar kampus unggulan utama di Lembaga Layanan Dikti (Kopertis VII) ini. Sehingga secara tidak langsung setiap tahunnya dosen-dosen dapat memamerkan karyanya melalui katalog buku yang sebelum proses cetak akan di buatkan rangkuman seluruh penulis untuk tiap semesternya. Alat pamer atau memamerkan buku ini juga terbatas pada katalog saja tidak dilakukan publikasi yang berlebihan, hal inilah yang menurut peneliti menjadi kurang memberikan penghargaan terhadap gagasan ide para dosen.

Wahana serta sarana untuk menceritakan buku-buku ini yang menurut peneliti masih kurang dan terbatas. Jika pada film-film kita kenal story telling sebagai sarana pamer atau cerita akan film yang akan segera ditayangkan, maka hal ini juga sangat perlu juga dilakukan pada buku-buku yang akan beredar. Story telling adalah sebuah teknik atau kemampuan untuk menceritakan sebuah kisah, 
pengaturan adegan, event, dan juga dialog. Kalau di film, para film maker bersenjatakan kamera; di komik, para komikus bersenjatakan gambar dan angle cerita; di cerpen atau novel, para penulis bersenjatakan pena, diksi, dan permainan kata serta deskripsi, dengan menyampaikan sebuah cerita dengan cara mendongeng. Story telling memberikan peran penting bagi siswa TK untuk membaca permulaan. (Ambarsari, 2015)

Mengingat pentingnya sarana pamer buku-buku unggulan tersebut maka untuk menciptakan sarana/perangkat pamer yang mirip dengan story telling, maka peneliti akan membuat sarana peralatan berupa etalase yang didesain sedemikian rupa untuk bisa untuk memamerkan buku dan memaparkan ceritanya secara singkat, sehingga perangkat ini dapat disebut dengan istilah booktory telling. Perangkat ini bisa menjadi tempat pamer utama dan menceritakan profil penulis dan isi buku serta jumlah halaman yang termuat dalam buku tersebut. Booktory telling akan menjadi sarana pamer yang akan dibaca lebih dulu sebelum buku itu benar-benar dijual secara bebas, daya tarik booktory telling juga seperti story telling yang memiliki manfaat dapat menarik perhatian pembaca. Dengan membingkai promosi dengan cerita yang menarik tentunya akan menjadi faktor ketertarikan pembaca untuk memperhatikan copy writing anda. Story telling membuat pesan anda mudah di ingat bagi pembaca. Membungkus copy writing tentunya akan mudah di ingat oleh pembacanya apalagi story telling yang dibuat memang menarik. Manfaat lainnya adalah pesan yang ingin anda sampaikan akan lebih mudah untuk difahami oleh pembaca. Tentunya ini akan sangat efektif jika diterapkan didalam iklan anda. Wardani (2010) bahwa sebuah desain furnitur yang berkualitas menyimpan nilai isoteri, mengandung kompleksitas nilai, baik ilmu pengetahuan dan ketrampilan teknik, muatan filosofi maupun metodologi.

Perancangan rak buku yang pernah dilakukan Syahrial (2015) juga menggambarkan untuk penerapan metode
Quality Function Deployment (QFD), bahwa responden sangat menginginkan rak buku yang ergonomi, dapat menampung banyak buku. Keefektifan penggunaan QFD ini menjadi latar belakang pemilihan alat analisis guna perancangan booktory telling yang akan dibuat dalam artikel ini. Puspita, dkk (2016) bahwa kayu masih menjadi pertimbangan utama sebagai dinamika budaya material, karena wooden furniture masih memiliki tingkat eksport tertinggi yaitu $67,02 \%$.

Konsep yang diterapkan dalam Quality Function Deployment (QFD) menurut penelitian Ardani (2014) menyebutkan penerapan desain meubel spring bed dengan metode QFD menunjukan bahwa kinerja karakteristik teknik dengan nilai tertinggi adalah karakteristik teknik part family dan kesamaan dasar struktur komponen dengan masing-masing nilai derajat kepentingan sebesar 20\%, Konsep dasar dari QFD yang sebenarnya adalah suatu cara pendekatan untuk mendesain produk agar dapat memenuhi keinginan konsumen. Konsep ini diperkenalkan oleh Yoji Akao, Professor of Management Engineering dari Tanagawa University yang dikembangkan dari praktek dan pengalaman industri-industri di Jepang. Pertama kali dikenal di Jepang pada tahun 1972 oleh perusahaan Mitsubishi, dan berkembang dengan berbagai cara oleh Toyota dan perusahaan lainnya. (Cohen L, 1995)

Tujuan dari penelitian ini adalah ; (1) Menganalisis rancangan booktory telling berupa perangkat pamer buku-buku ajar unggulan dengan $Q F D$ Analysis, (2) Membuat rancangan desain perangkat booktory telling yang menarik yang berdasarkan hasil analisa dari responden. (3) Membuat desain model produk secara spesifikasi (gambar 2D) dari perangkat booktory telling berdasarkan hasil analisa dari responden.

\section{METODE PENELITIAN}

Jenis penelitian yang digunakan dalam penelitian ini adalah penelitian pengembangan (Research and Development) 
Menurut Sugiyono (2011) metode penelitian dan pengembangan (Research and Development) adalah metode penelitian yang digunakan untuk menghasilkan produk tertentu, dan menguji keefektifan produk tersebut. Dalam melakukan aktivitas penelitian diperlukan suatu metode yang sesuai dengan alur penelitian yang akan dilakukan, sedangkan langkah-langkah penelitian dalam mengimplementasikan Quality Function Deployment terdiri dari empat tahap, yaitu matrik perencanaan produk, matrik pengembangan desain, matrik perencanaan proses, dan matrik perencanaan produksi sehingga tercipta rancangan pengembangan desain booktory telling, sebuah konsep yang di ambil dari manfaat story telling.

Sampel dalam penelitian adalah dosen dan mahasiswa di lingkungan Universitas PGRI Adi Buana Surabaya sekitar 86 orang. Teknik sampling yang dipergunakan adalah accidental sampling yaitu teknik pengambilan sampel dengan menentukan responden yang ada dan bersedia untuk menjadi sampel penelitian. Kriteria inklusi / pemilihan sampel ; (1) Dosen dan mahasiswa yang bersedia memberikan jawaban atas kuesioner yang disebarkan oleh peneliti, (2) Dosen yang sudah memiliki buku ajar dan ber-ISBN, (3) Dosen dan mahasiswa yang menjawab kuesioner lebih awal melalui aplikasi STRAW dengan batasan tanggal 30 Oktober 2018.

Analisa dalam penelitian ini menggunakan metode QFD (Quality Function Deployment) yang menmpertimbangkan ; matrik perencanaan produk, matrik pengembangan desain, matri perencanaan proses dan matrik perencanaan produksi. Untuk lebih lengkapnya dapat dilihat dalam gambar rancangan penelitian dibawah ini :

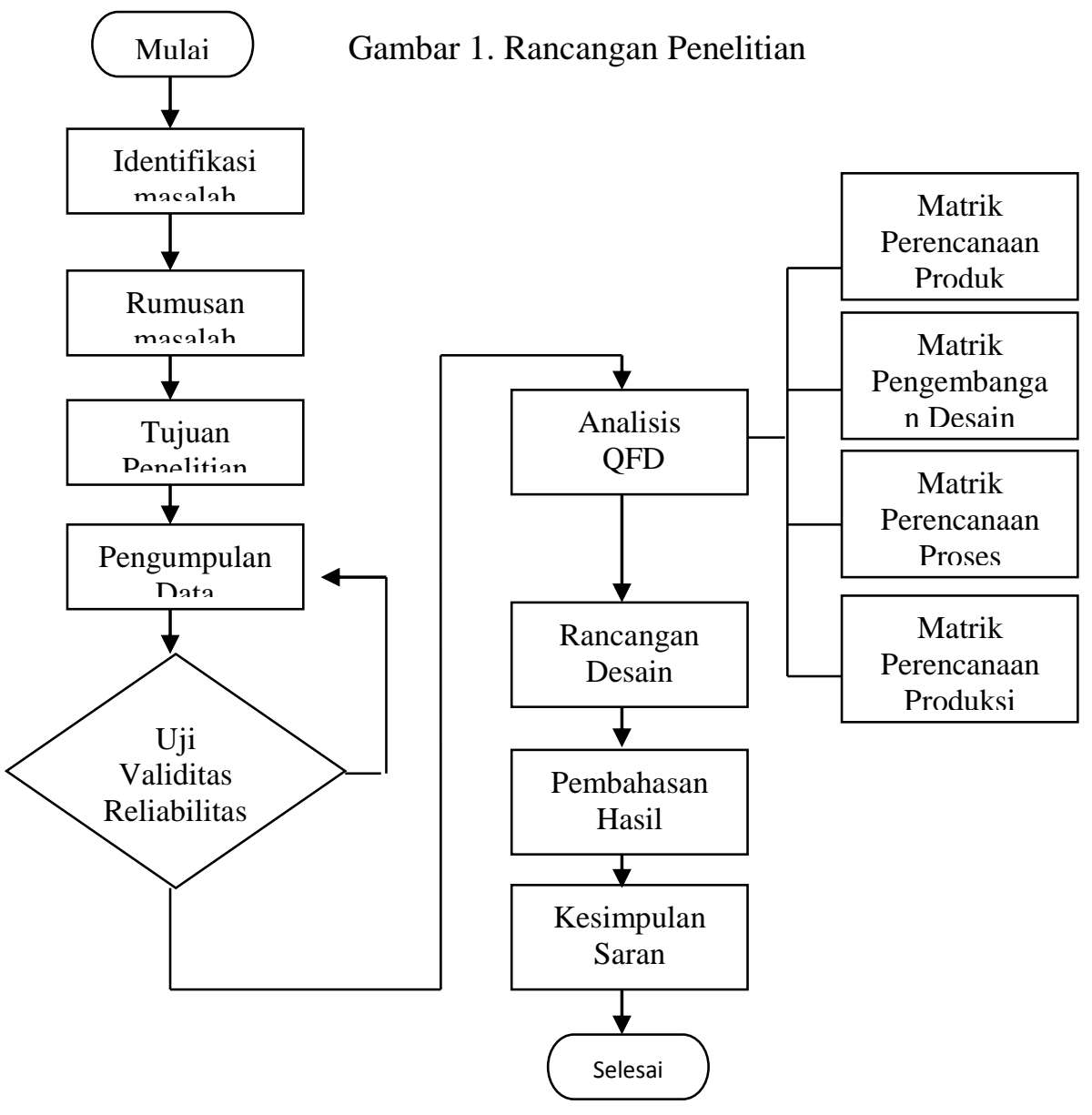




\section{HASIL DAN PEMBAHASAN}

\section{a. Data Identitas Responden}

Identitas responden merupakan data deskriptif yang memuat sebaran responden yang dijadikan objek penelitian, mengingat responden berada dikampus II Universitas PGRI Adi Buana Surabaya sebanyak 86 orang, maka datanya adalah sebagai berikut :

Tabel 1. Identitas Responden

\begin{tabular}{ccc}
\hline Identitas & $\begin{array}{c}\text { Frekuensi } \\
(\mathbf{n})\end{array}$ & $\begin{array}{c}\text { Persentase } \\
(\mathbf{\%})\end{array}$ \\
\hline Jenis Kelamin & & \\
Laki-laki & 39 & 45,3 \\
Perempuan & 47 & 54,7 \\
Status & & \\
Dosen & 60 & 69,8 \\
Mahasiswa & 26 & 30,2 \\
Total & $\mathbf{8 6}$ & $\mathbf{1 0 0}$ \\
\hline
\end{tabular}

Jenis kelamin ke-86 responden yang dijadikan sampelpenelitian ini yang laki-laki sebanyak 39 orang $(45,3 \%)$ dan yang perempuan sebanyak 47 orang $(54,7 \%)$. Status pekerjaan ke-86 responden yang dijadikan sampe lpenelitian ini yang selaku dosen sebanyak 60 orang $(69,8 \%)$ dan yang mahasiswa sebanyak 26 orang $(30,2 \%)$.

\section{b. Hubungan Data Identitas Responden dengan Pemilihan Tipe Desain Booktory Telling}

Data ini akan menjelaskan faktor-faktor dari identitas responden terhadap keinginan desain booktory telling yang akan dirancang

Tabel 2 : Hubungan Jenis Kelamin dengan Warna Booktory Telling

\begin{tabular}{lcccc}
\hline \multirow{2}{*}{$\begin{array}{c}\text { Jenis } \\
\text { Kelamin }\end{array}$} & \multicolumn{3}{c}{ Warna Booktory Telling } \\
\cline { 2 - 5 } & \multicolumn{2}{c}{$\begin{array}{c}\text { Warna Dasar } \\
\text { Biru }\end{array}$} & \multicolumn{2}{c}{$\begin{array}{c}\text { Warna Dasar } \\
\text { Merah }\end{array}$} \\
\cline { 2 - 5 } & $\mathbf{n}$ & $\mathbf{\%}$ & $\mathbf{n}$ & \% \\
\hline Laki-Laki & 12 & $14,0 \%$ & 27 & $31,4 \%$ \\
Perempuan & 4 & $4,7 \%$ & 43 & $50,0 \%$ \\
Total & 16 & 18,6 & 70 & $81,4 \%$ \\
Odd Ratio & 4,7 & & & \\
95\%CI & $1,397-16,341$ & & \\
\hline
\end{tabular}

Hasil analisis menunjukkan nilai $\mathrm{OR}=4,7$ $(95 \%$ CI $1,397<$ OR <16,341) artinya perempuan dalam memilih warna booktory telling dengan warna dasar merah kecenderungan 4,7 kali lebih banyak daripada laki-laki. Artinya pemilihan warna dasar merah lebih banyak dipilih sebagai dasar model desain serta yang banyak memberikan pilihan adalah perempuan.

\section{c. Hubungan Data Identitas Responden dengan Pemilihan Bahan Baku Desain Booktory Telling}

Data ini akan menjelaskan faktor-faktor dari identitas responden terhadap keinginan desain booktory telling yang akan dirancang

Tabel 3: Hubungan Jenis Kelamin dengan Bahan Baku Booktory Telling

\begin{tabular}{lcccc}
\hline \multirow{2}{*}{$\begin{array}{c}\text { Jenis } \\
\text { Kelamin }\end{array}$} & \multicolumn{2}{c}{ Bahan Baku Booktory Telling } \\
\cline { 2 - 5 } & \multicolumn{2}{c}{$\begin{array}{c}\text { Bahan Baku } \\
\text { Logam }\end{array}$} & \multicolumn{2}{c}{$\begin{array}{c}\text { Bahan Baku } \\
\text { Kayu }\end{array}$} \\
\cline { 2 - 5 } & n & \% & n & \% \\
\hline Laki-Laki & 15 & $17,4 \%$ & 24 & $27,9 \%$ \\
Perempuan & 16 & $18,6 \%$ & 31 & $36,0 \%$ \\
Total & 31 & $36,0 \%$ & 55 & $64,0 \%$ \\
Odd Ratio & 1,2 & & & \\
95\%CI & $0,501-2,929$ & & \\
\hline
\end{tabular}

Hasil analisis menunjukkan nilai $\mathrm{OR}=1,2$ $(95 \%$ CI $0,501<$ OR <2,929) artinya perempuan dalam memilih bahan booktory telling berupa bahan kayu kecenderungan 1,2 kali lebih banyak daripada laki-laki. Artinya pemilihan bahan baku kayu lebih banyak dipilih sebagai dasar model desain serta yang banyak memberikan pilihan adalah perempuan.

\section{d. Hubungan Data Identitas Responden dengan Jenis Story Telling Desain Booktory Telling}

Data ini akan menjelaskan faktor-faktor dari identitas responden terhadap keinginan desain booktory telling yang akan dirancang 
Volume 70, Nomor 2, 1 Desember 2018

Tabel 4 : Hubungan Jenis Kelamin dengan Jenis Story Telling pada Booktory Telling

\begin{tabular}{lcccc}
\hline \multirow{2}{*}{$\begin{array}{c}\text { Jenis } \\
\text { Kelamin }\end{array}$} & \multicolumn{2}{c}{ Jenis Story Telling } \\
\cline { 2 - 5 } & \multicolumn{2}{c}{$\begin{array}{c}\text { LCD } \\
\text { Screen }\end{array}$} & \multicolumn{2}{c}{$\begin{array}{c}\text { Artpaper } \\
\text { Screen }\end{array}$} \\
\cline { 2 - 5 } & $\mathbf{n}$ & \% & n & \% \\
\hline Laki-Laki & 15 & $17,4 \%$ & 24 & $27,9 \%$ \\
Perempuan & 12 & $14,0 \%$ & 35 & $40,7 \%$ \\
Total & 27 & $31,4 \%$ & 50 & $68,6 \%$ \\
Odd Ratio & 1,8 & & & \\
95\% CI & \multicolumn{2}{c}{$0,727-4,573$} & & \\
\hline
\end{tabular}

Hasil analisis menunjukkan nilai $\mathrm{OR}=1,8$ $(95 \%$ CI $0,727<$ OR <4,573) artinya perempuan dalam memilih jenis layar story telling berupa Artpaper Screen kecenderungan 1,8 kali lebih banyak daripada laki-laki. Artinya pemilihan artpaper screen lebih banyak dipilih sebagai jenis story telling serta yang banyak memberikan pilihan adalah perempuan.

\section{e. Analisa Quality Function Deployment (QFD)}

Berdasarkan hasil analisa Quality Function Deployment ( $Q F D$ ) dengan melihat house of quality dibawah ini maka dapat dilihat 3 prioritas yang tingkat kepentingannya paling tinggi sebagai berikut

1. Hasil Relative Important (RI) sebesar $25 \%$ diprioritaskan pada desain produk booktory telling berwarna merah mencolok dengan dasaran terbuat dari bahan HPL.

2. Hasil Relative Important (RI) sebesar $21 \%$ diprioritaskan pada pemilihan bahan yang kuat sehingga dipilih bahan multiplek

3. Hasil Relative Important (RI) sebesar $17 \%$ diprioritaskan pada bagian story telling yang menceritakan sekilas tentang buku dan identitas penulis yang terbuat dari artpaper screen.

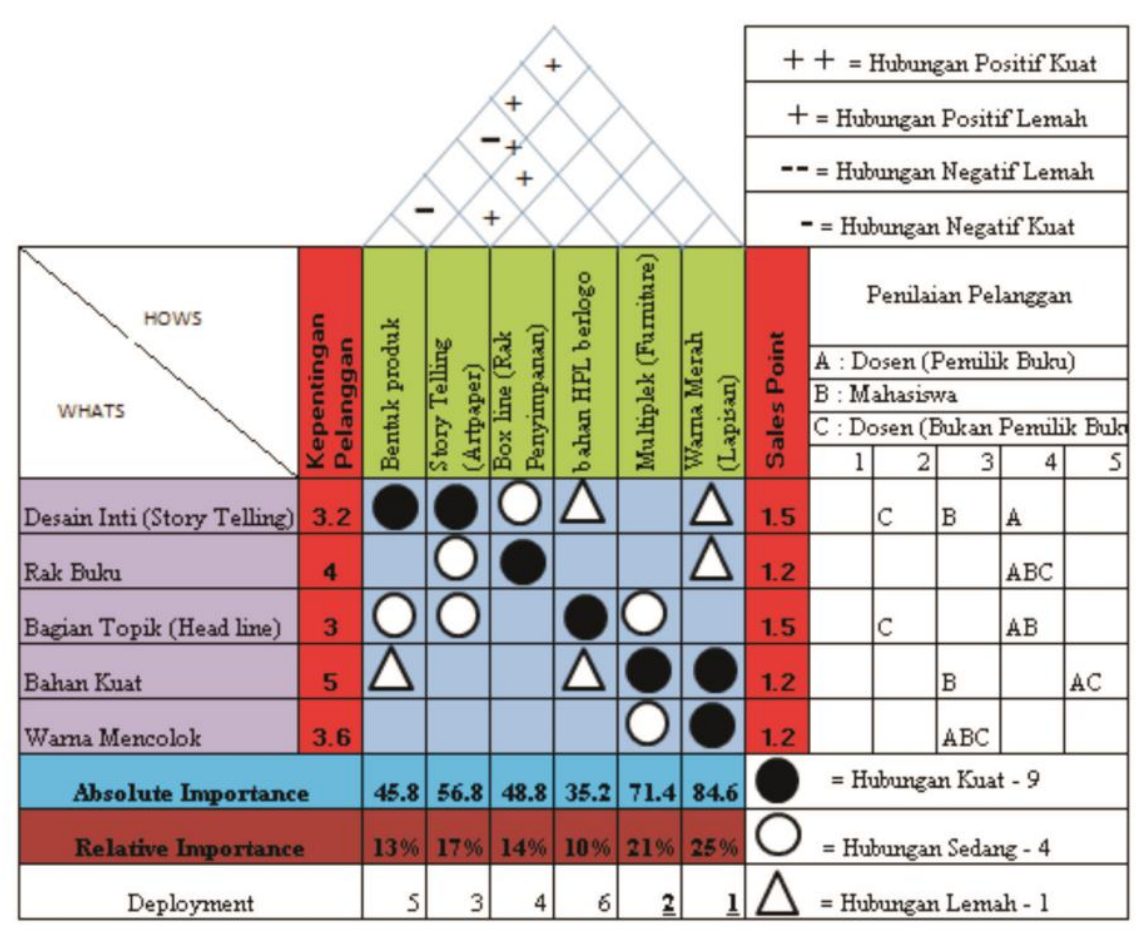

Gambar 2. House of Quality 


\section{f. Desain Perangkat Pamer Buku Ajar Booktory Telling}

Berdasarkan hasil analisa Quality Function Deployment (QFD) dengan melihat house of quality dibawah ini maka dapat digambarkan desain produk booktory telling sebagai berikut :
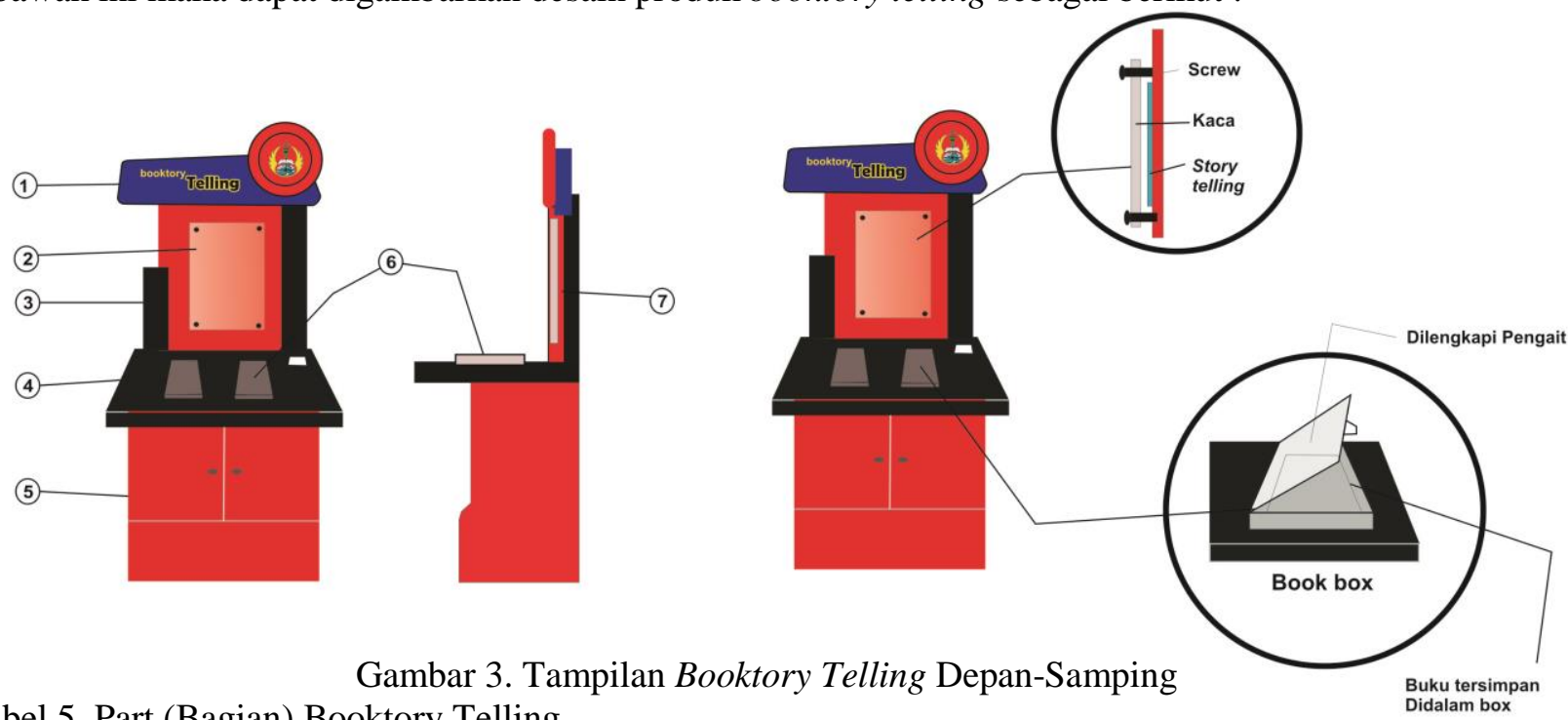

Tabel 5. Part (Bagian) Booktory Telling

Gambar 3. Tampilan Booktory Telling Depan-Samping

\begin{tabular}{|c|l|l|}
\hline $\begin{array}{c}\text { No. } \\
\text { Part }\end{array}$ & \multicolumn{1}{|c|}{ Nama Part } & \multicolumn{1}{c|}{ Spesifikasi } \\
\hline 1 & $\begin{array}{l}\text { Headline } \\
\text { Furniture }\end{array}$ & $\begin{array}{l}\text { Bahan multiple dengan HPL dan desain logo yang menggambarkan tema } \\
\text { dari Booktory telling }\end{array}$ \\
\hline 2 & $\begin{array}{l}\text { Story telling } \\
\text { buku }\end{array}$ & $\begin{array}{l}\text { Story telling berupa cerita tentang sejarah buku diciptakan, konten buku, } \\
\text { sejarah/riwayat penulis. Dicetak dalam kertas A3 dan dilapisi } \\
\text { kaca/hardboard clear }\end{array}$ \\
\hline 3 & $\begin{array}{l}\text { Tiang } \\
\text { Penyangga } \\
\text { headline }\end{array}$ & $\begin{array}{l}\text { Tiang penyangga headline furniture dibuat desain warna hitam kokoh } \\
\text { berlapis HPL }\end{array}$ \\
\hline 4 & Meja bookled & $\begin{array}{l}\text { Meja bookled berbahan multiplek yang digunakan untuk menempatkan } \\
\text { buku ajar (box buku) }\end{array}$ \\
\hline 5 & Foot Furniture & $\begin{array}{l}\text { Foot furniture merupakan bagian kaki penyangga booktory telling yang } \\
\text { sebenarnya berfungsi sebagai almari dengan dua daun pintu dua laci, } \\
\text { berfungsi juga untuk menampung buku }\end{array}$ \\
\hline 6 & Books box & $\begin{array}{l}\text { Book box merupakan kotak tempat menampung atau memamerkan buku } \\
\text { ajar }\end{array}$ \\
\hline
\end{tabular}

\section{KESIMPULAN}

Hasil penelitian tentang analisa desain produk booktory telling sebagai perangkat pamer buku ajar unggulan untuk dosen Unipa Surabaya, dapat disimpulkan sebagai berikut

1) Hasil Relative Important (RI) sebesar $25 \%$ diprioritaskan pada desain produk booktory telling berwarna merah mencolok dengan dasaran terbuat dari bahan HPL.

2) Hasil Relative Important (RI) sebesar $21 \%$ diprioritaskan pada pemilihan bahan yang kuat sehingga dipilih bahan multiplek

3) Hasil Relative Important (RI) sebesar $17 \%$ diprioritaskan pada bagian story telling yang menceritakan sekilas tentang 
buku dan identitas penulis yang terbuat dari artpaper screen.

\section{REFERENSI}

Cohen, Lou. 1995. Quality Function Deployment : How To Make QFD Work For You. Massachuset : Addison-Wesley Publishing Company.

Sugiyono, 2011. Metode Penelitian Kombinasi (Mixed Methods). Bandung: Alfabeta .

Syahrial, Muhammad Agyl Aminullah. 2015. Perancangan Produk Rak Buku Dengan Metode QFD (Quality Function Deployment). Skripsi. Universitas Wijaya Putra. Surabaya

Ardani, Febi, Rosnani Ginting dan Aulia Ishak, 2014. Perancangan Desain
Produk Spring Bed dengan Menggunakan Metode Quality Function Deployment, Jurnal, e-Jurnal Teknik Industri FT USU ISSN 2443-0579 online. Sumatera Utara

Ambarsari, Lelly. 2015. Penerapan Metode Story Telling Pada Kemampuan Membaca Permulaan Di Kelompok B3 Tk Budi Mulia 2 Pandeansari Yogyakarta. Jurnal. UNY. Yogyakarta

Wardani, Laksmi Kusuma. 2010. Perancangan Furnitur Perkantoran (Proses Desain, Manufaktur, Distribusi, Dan Konsumsi). Jurnal. Universitas Kristen Petra - Surabaya

Puspita, Arianti Ayu, Agus Sachari dan Andar Bagus Sriwarno. 2016. Dinamika Budaya Material pada Desain Furnitur Kayu di Indonesia. Jurnal. ITB. Bandung 